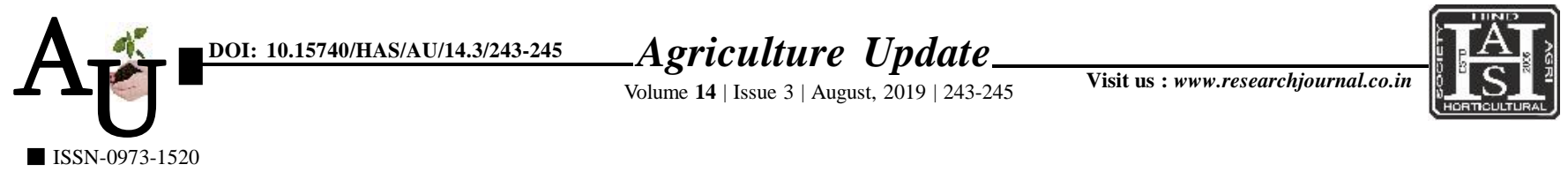

\title{
Rевевсн Автіск: Impact of frontline demonstrations on the yield and economic of pea in West Kameng district Arunachal Pradesh
}

\author{
Article Chronicle : \\ Received : \\ 19.06.2019; \\ Revised : \\ 15.07.2019; \\ Accepted : \\ 25.07.2019
}

KeY Words :

Pea, Yield, Improved technology, Benefit cost ratio
Author for correspondence :

\section{T. S. Mishra}

Krishi Vigyan Kendra,

West Kaameng

(Arunachal Pradesh)

India

Email: tarashankar

mishra2015@gmail.com

See end of the article for

authors' affiliations

\section{T.S. Mishra, H.M. Singh, N.K. Mishra, V.K. Mishra and N. D. Singh}

SUMMARY : The study was carried out during 2014 to 2017 at farmers field of dirang,West Kameng district of Arunacahal Pradesh. The front line demonstration on pea crop of seed was conducted on an area 18 ha for each variety with active participation of 40 farmers with improved technologies of VRP22, Arkel and Azad P1. The results revealed that maximum yield $23.0 \mathrm{q} / \mathrm{ha}$ with an increase over variety Arkel and Azad P1. Improved technology of pea recorded progressively increased average yield 20q/ ha during Three years of study, and minimum to maximum yield found17.0q/ha to $23.0 \mathrm{q} / \mathrm{ha}$. The extension gap can be bridged by popularizing package of practices of pea including improved variety (VRP-22), use of optimum seed rate, balanced nutrition and recommended plant protection measures. Improved technologies gave higher net return of Rs. 40,000/ha with benefit cost ratio 2.43 as compared to Azad P1 (Rs.29,800/- benefit cost ratio 2.06) and Arkel (Rs.1.94/-benefit cost ratio1.94).

How to cite this article : Mishra, T.S., Singh, H.M., Mishra, N.K., Mishra, V.K. and Singh, N.D. (2019). Impact of frontline demonstrations on the yield and economic of pea in West Kameng district Arunachal Pradesh. Agric. Update, 14(3): 243-245; DOI : 10.15740/HAS/AU/14.3/243-245. Copyright@ 2019: Hind Agri-Horticultural Society. 